\title{
The Internet Users' Opinions on Public E-Services
}

\author{
Empirical Analysis
}

\author{
Izabela Kapsa \\ Kazimierz Wielki University, Bydgoszcz, Poland \\ izabela.kapsa@ukw.edu.pl
}

\begin{abstract}
Public services are one of the most dynamically developing areas of the state's functioning, which is confirmed by the systematically increasing number of e-services and their users in individual countries. For more than 25 years, Poland has been gradually employing ICT in public administration services. The first honest public discussion on e-government started in 1994 after democratic transformation and accession to the European Union. However, the actual development of e-government in Poland began in 2005-2006. In Poland, the most significant number of people using e-government services was recorded in 2020 during the Covid-19 pandemic. Due to epidemic restrictions, citizens could deal with more official matters via the Internet. The main research problem in this article is related to Poles' declarations, opinions on the accessibility and use of public e-services offered, and their attitudes towards the availability and greater offer of e-services. The authors aimed to verify the hypothesis, assuming that Poles' declarations and opinions on electronic public services correlate with their time spent on the Internet each week. The issue has been presented in the form of an analysis of empirical data regarding Poles' experience and opinions on electronic administration tools (in the context of Internet usage) and statistical data regarding e-government development in Poland.
\end{abstract}

\section{CCS CONCEPTS}

- Applied computing; • Computers in other domains; • Computing in government; • E-government;

\section{KEYWORDS}

e-government in Poland, e-services, internet users, public services

ACM Reference Format:

Izabela Kapsa and Magdalena Musial-Karg. 2021. The Internet Users' Opinions on Public E-Services: Empirical Analysis. In 14th International Conference on Theory and Practice of Electronic Governance (ICEGOV 2021), October 06-08, 2021, Athens, Greece. ACM, New York, NY, USA, 6 pages. https://doi.org/10.1145/3494193.3494297

\section{INTRODUCTION}

The Covid-19 pandemic has undoubtedly had a significant impact on the functioning of the entire international community, also in

Permission to make digital or hard copies of all or part of this work for personal or classroom use is granted without fee provided that copies are not made or distributed for profit or commercial advantage and that copies bear this notice and the full citation on the first page. Copyrights for components of this work owned by others than the author(s) must be honored. Abstracting with credit is permitted. To copy otherwise, or republish, to post on servers or to redistribute to lists, requires prior specific permission and/or a fee. Request permissions from permissions@acm.org.

ICEGOV 2021, October 06-08, 2021, Athens, Greece

(c) 2021 Copyright held by the owner/author(s). Publication rights licensed to ACM ACM ISBN 978-1-4503-9011-8/21/10 .. \$15.00

https://doi.org/10.1145/3494193.3494297

\author{
Magdalena Musiał-Karg \\ Adam Mickiewicz University, Poznań, Poland \\ magdalena.musial-karg@amu.edu.pl
}

the public sphere. The consequences of lockdown and the dictation of social isolation and distance transferred many human activities and institutions to the Internet. Due to the dynamic development of e-government in recent years, the rules introduced during the pandemic have become an essential stimulus for providing an extension of public services to be realized via electronic tools. Also, citizens - owing to the impossibility of using administrative services traditionally - were mobilized, in a way, to deal with matters exclusively via internet platforms. In Poland, the largest number of users of public e-services was recorded in 2020. The experience of Poles in the use of public e-services, however, dates back several years. This part of the state's activity is based on local initiatives, national authorities' decisions, and European legal regulations. With further development of this area as a modern state goal, it is worth recognizing citizens' perceptions and expectations.

Such an unexpected situation extended the previously used information and communication technologies (ICT) in the public sphere, making them an essential tool for the provision of public services. The main research problem in this article is related to the declarations and opinions of Poles as Internet users about the accessibility and use of public e-services offered and their attitudes towards the availability and more excellent offer of e-services. The empirical analysis comes from the survey conducted in 2018 and it is supplemented with up-to-date statistical data obtained from public institutions. The article aims to answer the following research questions: If and to what extent do Poles use public e-services? What are their opinions regarding e-services offer in Poland and declarations to deal with official matters via the Internet? Does the time spent using the Internet differentiate the respondents' opinions about e-services? The publication contains an analysis of the answers obtained in the survey that relate to the questions posed. The authors aim to verify the following research hypothesis: Poles' declarations and opinions about electronic public services differ depending on the amount of time spent on the Internet each week. People using the Internet are more likely to use and better evaluate public e-services.

\section{THE STATE OF PUBLIC E-SERVICES IN POLAND}

Digital public services are one of the significant dimensions of egovernment. According to many definitions, e-government refers to the use of ICTs by government agencies to improve the delivery of information and public services to its citizens through transparent and accountable means [1] [2] [3]. The idea of e-government appeared in Poland about 25 years ago. The development of electronic undertakings implemented by the Polish government was closely associated with the integration processes. Before the EU accession, Poland had to fulfill a number of conditions, including some related 
Table 1: Public services available via Internet in Poland (2018)

Website made to WCAG 2.0

Website adjusted to mobile phones and other mobile devices

Services offered via Internet in area of civic matters

Services offered via Internet in area of work

Services offered via Internet in area of enterprise

Services offered via Internet in area of taxes

\begin{tabular}{ll} 
STATE ADMINISTRATION & LOCAL ADMINISTRATION \\
$81.3 \%$ & $91.1 \%$ \\
$74.8 \%$ & $74.8 \%$ \\
$49 \%$ & $83.1 \%$ \\
$25 \%$ & $13.2 \%$ \\
$15 \%$ & $41.7 \%$ \\
$5 \%$ & $51.6 \%$ \\
\hline
\end{tabular}

to the implementation of e-government solutions [4]. Then, the concept of e-government was explicitly referred to in the Information Society Development Strategy until 2013 [5]. The development of e-government in Poland is currently based on documents that indicate directions for evolving policies and services.

According to Statistics Poland [6], in 2020, 81.4\% of Poles aged 16-74 used the Internet regularly (at least once a week). In comparison it was $78.3 \%$ in 2019 and $74.8 \%$ in 2018]. The rate in the European Union in 2018 was $87 \%$. Poland's distance to the EU average remained at 5 percentage points. The largest share of regular internet users was recorded in countries that have been at the forefront of this type of rankings in the EU for many years - Norway and Sweden (98\% each), Denmark and Luxembourg (97\% each) as well as the Netherlands and the United Kingdom (96\% each). The lowest percentage of internet users was recorded in Bulgaria (71\%), Greece, and Portugal (both 76\%) [7].

In $2018,96.6 \%$ of public administration bodies provided electronic services to citizens [8]. The largest number of them offered e-services in the area of civic matters (81.9\%). Figures concerning e-services provided are in table 1. Even though many services are classified as e-services, they are not entirely digital in practical terms. In certain situations, a visit to the office to collect a document or put a signature was necessary, and only a form could be sent over the Internet. A showcase example, and at the same time one of the first e-services offered, is the payment of taxes. For several years, mandatory annual tax returns can be filed through a computer program of eDeklaracje. Since 2019 an electronic version of a tax return is developed by the Ministry of Finance and available online.

Among public e-services, in 2018, most popular was looking for information on the website (24.40\%), downloading official forms (22\%), and sending official forms $(24.60 \%)$, including tax returns (20.50\%). In recent years, the group of people downloading forms and sending them back after filling in has been growing.

Currently, out of 185 public services, Poles can provide 51 online services on various platforms and government portals. These include Electronic Platform of Public Administration Services (ePUAP), Electronic Services Platform of the Social Insurance Institution (PUE ZUS), obywatel.gov.pl (citizens.gov.pl) portal, biznes.gov.pl portal. At present, the Portal of the Republic of Poland is under construction, which will ultimately be the gateway to all public information and e-services. It will integrate websites of ministries, central offices, and provincial offices and facilitate access to digital services that the state offers to citizens. The challenge is to create a space where one address will contain the entire scope of e-government, www. It is in line with the EU recommendations and practiced by the leaders of e-government in the world (e.g., Estonia: e-estonia.com).

The development of e-government in Poland in recent years has been influenced by both greater access to the Internet infrastructure, growing digital competencies of the society, and the development and constantly increasing the number of available online public services. In recent years, many people searching for information, downloading forms, and returning completed documents to offices via the Internet have increased [6]. According to Statistics Poland, almost $42 \%$ of people aged 16-74 in Poland contact the public administration via the website. In 2020, the percentage of people obtaining information from websites of public authorities increased by 2.3 pp., and those sending completed forms - by $2.1 \mathrm{pp}$., compared to the previous year. The data in Table 2 show that the share of public administration e-customers has increased each subsequent year, regardless of the type of activity.

2020 was a record year for the use of e-government tools. It was obviously related to the Covid-19 pandemic and the lockdown which followed. On average, over 11,000 Poles set up a trusted profile every day, and offices received almost four thousand electronic general letters every day. From January 1 to December 31, 2020, precisely 4,174,206 Poles set up a trusted profile. It is almost half $(47 \%)$ of all currently active trusted profiles $(8,816,654)$. It is also over two million more than in 2019 and almost three million more than in 2018 [9]. The most popular form of online contact with an office was sending general letters to offices. The second most popular e-service was applying for a copy of the marital status certificate. The child's birth was also reported online, and e-registration services were used, and online applications for ID cards were submitted. Therefore, one may conclude that Poles are more and more willing to use public services online, which is also confirmed by the unprecedented increase in the number of new trusted profiles on the public e-services platform. New, more and more intuitive websites and applications enabling the use of e-services are also systematically created.

However, it is worth noting that Poland's progress does not look so optimistic compared to other countries. In the latest report containing the digital economy and society index results-Digital Economic and Society Index, Poland was ranked sixth from the bottom of the 28 Member States of the European Union [10]. Such a low overall result for Poland was significantly lower than the European average for four out of five area indicators: human capital, use of internet services by citizens, integration of digital technologies, and digital public services. Only in terms of connectivity, Poland achieved a result slightly higher than the average for the entire group (chart 1). 
Table 2: Individuals using e-government services in the last 12 months

\begin{tabular}{|c|c|c|c|c|c|}
\hline & 2016 & 2017 & 2018 & 2019 & 2020 \\
\hline & \multicolumn{5}{|c|}{$\%$ of all people } \\
\hline $\begin{array}{l}\text { Individuals using e-government services } \\
\text { in order to: }\end{array}$ & 30,2 & 30,8 & 35,5 & 40,4 & 41,9 \\
\hline $\begin{array}{l}\text { obtain information from websites of public } \\
\text { authorities }\end{array}$ & 22,8 & 20,6 & 24,4 & 24,9 & 27,2 \\
\hline download official forms & 19,0 & 20,2 & 22,1 & 24,6 & 25,4 \\
\hline submit completed forms & 18,8 & 21,0 & 24,6 & 31,4 & 33,5 \\
\hline
\end{tabular}

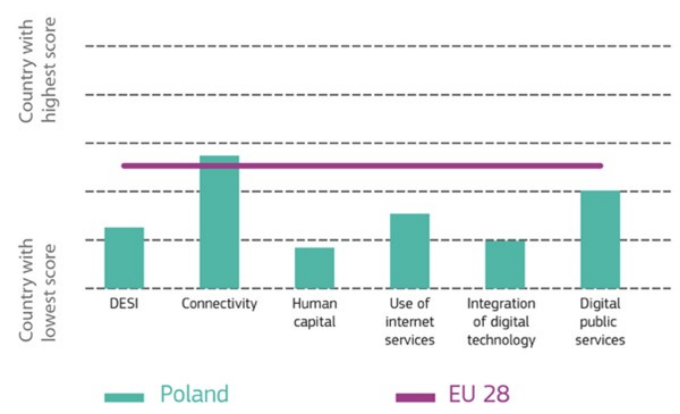

Figure 1: Digital Economy and Society Index - Poland

The position of Poland is slightly better compared to the United Nations member states. According to the E-Government Development Index 2020 [11], which presents the state of development of electronic administration, Poland ranks $24^{\text {th }}$ out of 193 surveyed countries. Compared to the 2019 report, Poland moved up 9 places but is still lagging behind most European countries. When it comes to the position of Poland against the background of 42 European countries included by EGDI - Poland ranks $16^{\text {th }}$ among the European countries.

However, considering all the components of the EGDI index, it can be noted that over the years 2005-2020, there has been a visible increase in the value of the Telecommunication Infrastructure Index and Online Service Index in Poland. This increase indicates the development of the ICT infrastructure and the development of the e-services sector. It is also worth noting that the value of the E-Government Development Index for Poland is higher than the average EGDI value for Europe - 0,8170 and than the world average EPI - 0,5988. The value of the indicator (especially in the
European context) allows us to conclude that the development of e-government places Poland slightly above the European average.

\section{INTERNET USERS OPINIONS ON PUBLIC E-SERVICES: EMPIRICAL ANALYSIS}

This part of the article contains the presentation of research results on Poles' opinions on the public e-services. The study was conducted between April and June 2018 throughout Poland. The sample of respondents numbered 1716 Poles and was selected in a quota manner, taking into account the demographic characteristics of the population. Then, according to sex and age, the sample size concerning the population was determined. After meeting these criteria, the subjects were selected using the snowball method. Most of the respondents chosen in this way completed the paper version of the questionnaire. It was also possible to use the electronic version available to all network users.

\subsection{Methodology}

Among all the questions asked and the statements made in the survey, the article presents the average results of responses to the statements relating to e-government and public e-services, taking into account the relationship between the answers and the time spent on the Internet every week. The research results on e-services in the opinions of Poles presented below are based on two statements that refer to their experience with e-services and their declaration to use them more often if possible.

The empirical analysis is based on answers given by respondents to the following statements included in the questionnaire:

- I use electronic administration services (e.g., I send documents to institutions over the Internet, send emails to authorities, send my tax returns via Internet, etc.).

Table 3: E-Government Development Index - Poland, 2005-2020

\begin{tabular}{|c|c|c|c|c|c|c|c|c|}
\hline & 2005 & 2008 & 2010 & 2012 & 2014 & 2016 & 2018 & 2020 \\
\hline EGDI Poland & 0,58721 & 0,6134 & 0,55822 & 0,64414 & 0,64822 & 0,72108 & 0,7926 & 0,8531 \\
\hline Online Service Index value & 0,51153 & 0,53846 & 0,3873 & 0,53594 & 0,5433 & 0,7029 & 0,9306 & 0,8588 \\
\hline $\begin{array}{l}\text { Telecommunication } \\
\text { Infrastructure Index value }\end{array}$ & 0,2901 & 0,34814 & 0,33737 & 0,49211 & 0,56182 & 0,58568 & 0,5805 & 0,8005 \\
\hline Human Capital Index value & 0,96000 & 0,95595 & 0,95516 & 0,90435 & 0,8396 & 0,87465 & 0,8668 & 0,9001 \\
\hline
\end{tabular}

Source: EGDI-Poland, 2020. 
Table 4: Answers to statements on public e-services

\begin{tabular}{l}
$\begin{array}{l}\text { Statement } 1 \text { I I use electronic administration services (e.g., I send documents to institutions over Internet, I send email to authorities, I send } \\
\text { my tax returns via Internet etc.) (\% of answers) }\end{array}$ \\
\hline \hline 5 \\
\hline \hline
\end{tabular}

- I would like to have more opportunities to deal with official matters over the Internet in Poland.

Answers were expressed by using the Likert scale, so the respondents could choose one out of five possible options: definitely yes, rather yes, yes, hard to say, rather no, definitely no. While processing results, each option was coded in numbers as follows: definitely yes -5 points, rather yes -4 points, hard to say -3 points, rather no -2 points, definitely no - 1 point.

Information on using the Internet was obtained from the question: How many more or fewer hours a week do you usually spend on the Internet? The answers of the respondents were arranged in a cafeteria containing seven categories: 1 . I do not use the Internet; 2. up to 2 hours; 3 . from 3-7 hours; 4. from 8-21 hours; 5 . from 22-35 hours; 6.36 hours and more; 7. It's hard to say.

The analysis of basic descriptive statistics is accompanied by Kolmogorov-Smirnov tests, Kruskal-Wallis tests, and post-hoc DunnSidak tests. The significance level was determined at the classical cut-off value $\alpha=0.05$; Abbreviations used in the tables: AVG - average; K-S - Kolmogorov-Smirnov tests; $\mathrm{p}$ - statistical significance.

\subsection{Results of empirical research}

The primary descriptive statistics (table 4) presented as percentage of answers show that for the first statement (I use electronic administration services), nearly $70 \%$ of respondents (the average of 3.46) answered "yes" (closely: "definitely yes" or "rather yes") and for the statement two (I would like to have more opportunities to deal with official matters over the Internet in Poland) nearly $80 \%$ of respondents answered "yes" (average for their answers was 4.28). We may argue that they express the expectation towards public services to be provided online because if someone uses e-government services, they would like to have more such services offered [12].

A series of analyses were performed using the Kruskal-Wallis test to verify the research question whether the time spent on using the Internet every week differentiates the level of responses regarding electronic responses. It turned out to be statistically significant. The results are presented on charts 2 and 3.

The result of the analysis of respondents' responses to the first statement (I use electronic administration services) using the Kruskal-Wallis test was statistically significant $(H(6)=248.19 ; p$ $<0.001)$. Dunn-Sidak's post-hoc tests showed a significant difference between non-internet users and all other groups ( $p=0.001$ in all cases), and between the "hard to say" group and groups using Internet up to 2 hours weekly $(\mathrm{p}=0.002)$ and $3-7$ hours $(p=0.003)$. There was also a difference in the statistical trend between the "hard to say" group and the 8-21 hour group $(p=0.075)$. The other differences were not even close to statistical significance.

Three groups recorded the highest average results of responses to this statement: people using the Internet more than 36 hours weekly (AVG 3.74), 22-35 hours (AVG 3.72), and "hard to say" (AVG 3.96); lowest in the group of non-users (AVG 1.40).

Also, the result of the analysis of respondents' responses to the second statement (I would like to have more opportunities to deal with official matters over the Internet in Poland) was statistically significant $(H(6)=367,27 ; p<0,001)$. Dunn-Sidak's post-hoc tests showed a significant difference between the following groups:

- non-internet users and all other groups $(p<0,001)$;

- people using internet up to 2 hours weekly and 22-35 hours ( $p=0,041), 8-21$ hours $(p<0,001)$, "hard to say" $(p<0,001)$ and more than 36 hours $(p<0,001)$;

- people using internet 3-7 hours weekly and group "hard to say" $(p=0,001)$ and more than 36 hours $(p<0,001)$.

The highest average results for this statement were recorded in three groups: people using more than 36 hours weekly (AVG 4.66), 8-21 hours (AVG 4.51), 22-35 hours (AVG 4.50), and "hard to say" (AVG 4.63); the lowest again in the group of non-users (AVG 2.38). In each group, however, this result was higher than in the previous statement.

\subsection{Discussion}

As the number of Internet users in the world is steadily increasing, researching citizens as users of public e-services is an interesting subject of scientific research. However, the analysis of public eservices users is usually not undertaken together with the study of Internet use. The research on the number of people using the Internet is carried out by organizations such as International Telecommunication Union (ITU), We Are Social and Hootsuite's or Internet World Stats. According to them, in 2019, there were around 4 billion Internet users in the world [12], which is twice as high as in 2010. It is worth emphasizing that this means that currently more than half of the world's population uses the Internet. However, it should be noticed that North America and Europe are the leaders when it comes to the Internet penetration rate, which is $90.3 \%$ and $87.2 \%$ respectively [13]. In the rest of the world, digital exclusion is a big problem in the context of technological advances.

Thus, research on digital service users is conducted mainly in those countries where these services are available, both thanks to the use of ICT infrastructure by state and local authorities as well as to the Internet access of their citizens. Despite this, many 


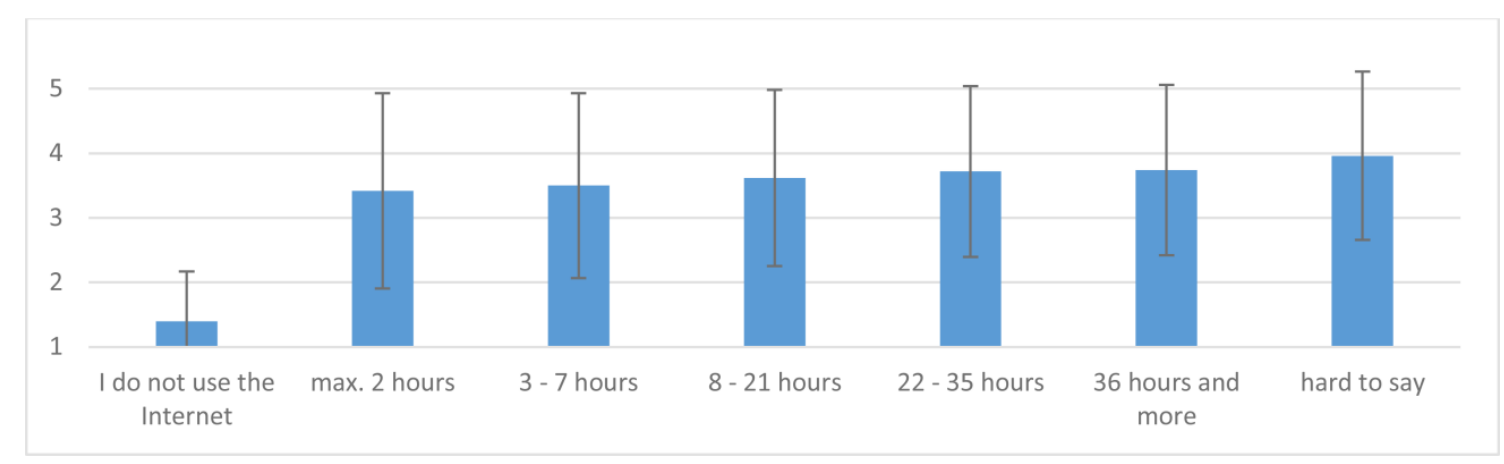

Figure 2: Time spent on using the Internet (weekly) and the opinion on the statement: I use electronic administration services

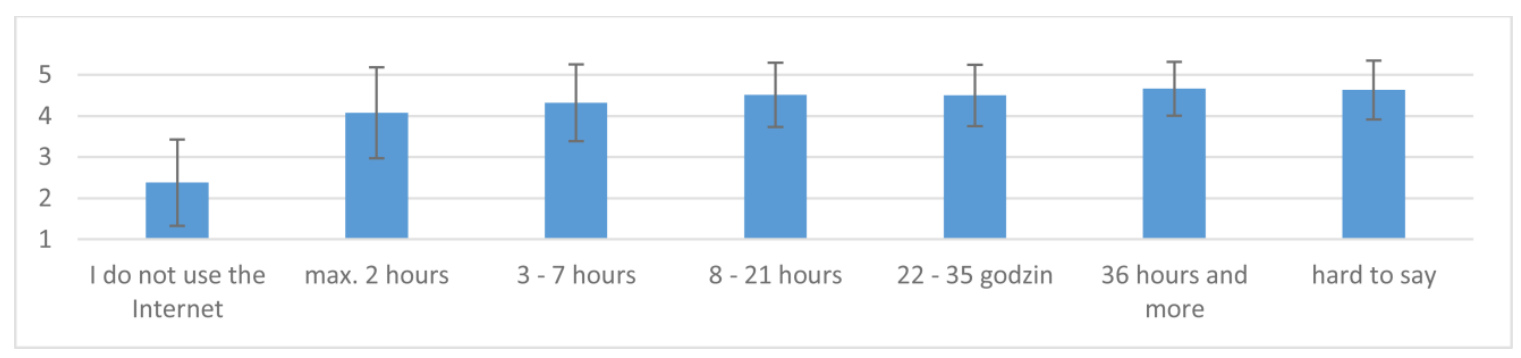

Figure 3: Time spent on using the Internet (weekly) and the opinion on the statement: I would like to have more opportunities to deal with official matters over the Internet in Poland

publications do not analyze public e-services in the perspective presented in this article. For example, the causes of the gap between the actual and potential use of e-services in the Netherlands were defined as a lack of knowledge of services and the need to acquire the skills to use them [14]. The similar conclusions were made by the authors who investigated the causes of low participation in e-services among older people [15]. One of the few examples of research devoted to e-service users in the context of access to technology is the publication presenting citizen motives for not using electronic government services [16]. Findings show a higher than expected importance of hardware and internet availability, as well as the importance of convenience factors for non-adoption.

Which is interesting here, researching citizens as users of public e-services complies with market orientation in the public sector. For the last few years, e-government analyses have been developed from the perspective of public organizations based on internal organizational needs [17] to market orientation resting on the needs of the end-users [18]. Noticing the vital role of citizens, organizations - also in the public sector - are market-oriented and focus on their customers' needs and wants [19]. In line with this orientation, the analysis presented in this article managed to identify public e-services users and their general needs. The analysis results indicate that people using public e-services in Poland expect there to be more such opportunities. Moreover, those who use the Internet both use public e-services more often and would like to see more of them. These findings encourage further research in this direction. They also mark the starting point for marketing strategy and activities. The critical issue is understanding who the customers are and appreciating their needs and behaviors [19].
Determining the characteristics of users is essential to use market segmentation - the process by which marketers perceive a market by dividing it into subsets of customers who behave in the same way or have similar needs. The dimensions or characteristics of individuals used to divide a total market into segments are usually referred to as segmentation variables: geographic, demographic and socio-economic, psychographic, behavioral [20]. Internet users are located in the behavioral dimensions. In our previous article, we conducted a geographic, demographic, and socio-economic analysis [21], the analysis is also available in a broader scope in the book devoted to the opinions of Poles on e-government and e-voting [22]. The challenge is to recognize psychographic dimensions, which are either for further analysis or can be made by using an algorithm. According to Kosinski, Stillwell, and Graepel wide variety of people's personal attributes can be automatically and accurately inferred using their Facebook Likes [23]. They have demonstrated a high degree to which relatively basic digital records of human behavior can be used to automatically and accurately estimate a wide range of personal attributes that people would typically assume to be private. It lets predict users' individual attributes and preferences can be used to improve numerous products and services. However, with regard to e-service users, the application of the algorithm may not be that simple. Not every citizen uses social media. Moreover, combining these two sources of information also seems troublesome. 


\section{CONCLUSIONS}

Public e-services are one of the most dynamically developing areas of the public administration functioning, which is confirmed by the systematically increasing number of e-services and their users in particular countries. In Poland, dynamic development of this sector of public activity has been observed for many years (which is confirmed by international rankings, including the E-Government Development Index). 2020 was an exceptional year in this respect due to the pandemic that continued as an accelerator for the increased interest of citizens in using public services provided via the Internet.

Answering the research questions, the authors state that Poles use more and more public e-services year after year. In last years they use it mainly to obtain information from websites of public authorities, download official forms or submit completed forms. As the results of the survey show Poles want to use more e-services and deal with official matters via the Internet (almost $80 \%$ of the positive answers). Moreover, people spending more time on the Internet are more likely to use and better evaluate e-government. The hypothesis has been positively verified. There have been statistically significant differences between people who do not use the Internet and all other groups, to use e-government services. The general conclusion from this survey is that Poles would like more services to be provided electronically. The more they use the Internet themselves, the more services they would like to do this way. The more they use public e-services, the more citizen activities they would like to take electronically. Considering market orientation in the public sector, it would be interesting for further analysis to recognize more precise needs of citizens as customers of public e-services. Since Poland's results compared to other European countries indicate the necessity to take measures to develop this area of state activity, it is crucial information both from the point of view of research and practical implications.

\section{ACKNOWLEDGMENTS}

This article has been written within the research project: E-voting as an alternative way of voting procedures in national elections. Experiences of selected countries and prospects for implementation e-voting in Poland (E-voting jako alternatywna procedura głosowania w elekcjach państwowych. Doświadczenia wybranych państw a perspektywy wdrożenia e-głosowania w Polsce) - financed by the National Science Center in Poland UMO-2014/15/B/HS5/01358.

\section{REFERENCES}

[1] Benjamin D. Huffman. 2017. E- Participation in the Philippines: A Capabilities Approach to Socially Inclusive Governance. eJournal of eDemocracy and Open Government (JeDEM), vol. 9 no. 2, 24-46. https://doi.org/10.29379/jedem.v9i2.461.

[2] William H. Dutton. 1999. Society on the Line: Information Politics in the Digital Age. Oxford University Press.
[3] OECD. 2003b. The e-government imperative. OECD e-Government Studies. Paris. Retrieved from https://read.oecd-ilibrary.org/governance/the-e-governmentimperative_9789264101197-en\#page1.

[4] Krystyna Doktorowicz. 2005. Europejski model społeczeństwa informacyjnego. Wydawnictwo Uniwersytetu Śląskiego, Katowice.

[5] Strategia rozwoju społeczeństwa obywatelskiego w Polsce do roku 2013, Ministerstwo Spraw Wewnętrznych i Administracji, 2008. Warszawa.

[6] Statistics Poland. 2020. Information society in Poland in 2020. WarszawaSzczecin. Retrieved December 10, 2020 from https://stat.gov.pl/obszarytematyczne/nauka-i-technika-spoleczenstwo-informacyjne/spoleczenstwoinformacyjne/spoleczenstwo-informacyjne-w-polsce-w-2020-roku, 1, 14.html

[7] Eurostat Database. 2021. Individuals - internet use. Retrieved December 10, 2020 from https://ec.europa.eu/eurostat/databrowser/view/isoc_ci_ifp_iu/ default/table?lang=en

[8] Statistics Poland. 2018. Reports on Wykorzystanie technologii informacyjnokomunikacyjnych w jednostkach administracji publicznej, przedsiębiorstwach i gospodarstwach domowych w 2018 roku. Retrieved September 3, 2019 from www.stat.gov.pl.

[9] Digital Affairs - Chancellery of the Prime Minister. 2021. E-usługowe podsumowanie 2020 r. Retrieved December 10, 2020 from https://www.gov.pl/web/ cyfryzacja/e-uslugowe-podsumowanie-2020-r

[10] DESI. 2020. Digital Economy and Society Index - Poland. Retrieved November 10, 2020 from https://ec.europa.eu/digital-single-market/en/scoreboard/poland

[11] EGDI. 2020. E-Government Development Index - Poland. Retrieved November 10, 2020 from https://publicadministration.un.org/egovkb/en-us/Data/CountryInformation/id/135-Poland

[12] Statistics, International Telecommunication Union. Retrieved December 12, 2020 from https://www.itu.int/en/ITU-D/Statistics/Pages/stat/default.aspx

[13] Internet World Stats. 2020. Retrieved November 14, 2020 from https://www. internetworldstats.com/stats.htm

[14] Jan A.G.M. van Dijk, Willem Pieterson, Alexander J.A.M. van Deuren, Wolfgang Ebbers. 2007. E-Services for Citizens: The Dutch Usage Case. In Wimmer M.A., Scholl J., Grönlund A. (eds). Electronic Government. EGOV 2007. Lecture Notes in Computer Science, vol 4656. Springer, Berlin, Heidelberg. https://doi.org/10. 1007/978-3-540-74444-3_14

[15] Koldo Zabaleta, Diego López-de-Ipiña, Enrique Sanz, Ane Irizar-Arrieta, Vincenzo Cartelli, Giuseppe D. Modica, and Orazio Tomarchio. 2018. Human Computation to Enhance E-Service Consumption among Elderlies. In Proceedings 2, no. 19: 1221. https://doi.org/10.3390/proceedings2191221.

[16] Steven van de Walle, Zane Zeibote, Sergejsb Stacenko, Tatjanab Muravska, Koena Migchelbrink. 2018. Explaining Non-adoption of Electronic Government Services by Citizens: A Study Among Non-users of Public E-services in Latvia. Information Polity, vol. 23 no. 4, 399-40. https://doi.org/ 10.3233/IP-170069.

[17] Christopher G. Reddick. 2004. Citizen interaction with e-government: From the streets to servers? Government Information Quarterly vol. 22, 38-57. https: //doi.org/10.1016/j.giq.2004.10.003

[18] Löfstedt U. 2007. E-Government Services in Local Governments - A Study of Development in Swedish Municipalities. Journal of Organisational Transformation and Social Change 4(2), pp. 157-176.

[19] Åsa Wallström, Anne Engström, Esmail Salehi-Sangari and Maria Ek Styvén. (2009). Public E-Services from the Citizens' Perspective - Adopting a Market Orientation. International Journal of Public Information Systems, vol. 2 no. 2, 123-134.

[20] Dibb, Sally Simkin, Lyndon, Pride William M. and Ferrell, O. C. 2005. Marketing: Concepts and Strategies 5th European. Abingdon, UK: Houghton Mifflin.

[21] Izabela Kapsa, Magdalena Musiał-Karg. 2020. E-Government in Poland in public data and opinions of Poles: an empirical analysis. In Proceedings of the 13th International Conference on Theory and Practice of Electronic Governance (ICEGOV 2020). Association for Computing Machinery, New York, NY, USA, 419-429. https://doi.org/10.1145/3428502.3428559.

[22] Natasza Lubik-Reczek, Izabela Kapsa, Magdalena Musiał-Karg, M. 2020. Elektroniczna partycypacja obywatelska w Polsce. Deklaracje i opinie Polaków na temat e-administracji i e-głosowania, Poznań

[23] Michal Kosinski, David Stillwell and Thore Graepel. 2013. Private Traits and Attributes Are Predictable from Digital Records of Human Behavior. In Proceedings of the National Academy of Sciences 110.15, 5802-5805. https://doi.org/10.1073/ pnas. 1218772110 . 